BBA 76032

\title{
THE TRYPSIN-CATALYZED HYDROLYSIS OF MONOMOLECULAR FILMS OF LYSYLPHOSPHATIDYLGLYCEROL
}

\author{
R. M. GOULDa, ${ }^{\star}$ AND R. M. C. DAWSONb \\ a Biochemistry Laboratory, State University, Utrecht, Vondellaan 26, Utrecht (The Netherlands); \\ and bDepartment of Biochemistry, A.R.C. Institute of Animal Physiology, Babraham, Cambridge, \\ CB2 $4 A T$ (Great Britain)
}

(Received February 9th, r972)

(Revised manuscript received June 5th, 1972)

SUMMARY

The hydrolysis by trypsin of the bacterial phospholipid, lysylphosphatidylglycerol has been studied at the air-water interface. High specific activity $\left[{ }^{14} \mathrm{C}\right]-$ lysylphosphatidylglycerol was prepared biosynthetically and the trypsin action followed by measuring the loss of surface radioactivity from a monolayer of the phospholipid spread on a water surface. After a lag phase, hydrolysis proceeded at a constant rate proportional to the enzyme concentration until 50-85\% of the substrate had been hydrolysed. Maximum hydrolysis occurred between I0-35 dynes/cm surface pressure and at $\mathrm{pH}$ 7.5-8.5. A slight fall in the surface pressure occurred but this was less than predicted from the force-area curves of lysylphosphatidylglycerol and phosphatidylglycerol.

$\mathrm{Ca}^{2+}(0.5 \mathrm{mM})$ and to a lesser extent $\mathrm{Mg}^{2+}$ and $\mathrm{Sr}^{2+}$ stimulated the reaction. During the reaction ${ }^{45} \mathrm{Ca}^{2+}$ became bound to the monolayer in proportion to the extent of the enzymic hydrolysis. The stimulation by calcium required the synergic presence of low concentrations of Tris buffer. High concentrations of $\mathrm{CaCl}_{2}(2 \mathrm{mM})$, $\mathrm{NaCl}(25 \mathrm{mM})$, Tris buffer $(47 \mathrm{mM})$ almost completely inhibited the reaction. Chlorpromazine, which removes $\mathrm{Ca}^{2+}$ from phospholipid membranes, markedly stimulated hydrolysis at $2.5-6.0 \mu \mathrm{M}$, but only in the presence of added calcium: higher concentrations of chlorpromazine (o.125 mM) completely inhibited the reaction.

\section{INTRODUCTION}

Monomolecular lipid films spread at an air-water interface have been used as one means to circumvent the difficult problem in the area of lipid-lipid and lipidprotein interactions of controlling the physical state of the lipid in aqueous solution. In this paper we are using monolayers to study a novel enzymic reaction, the hydrolysis of the bacterial phospholipid, lysylphosphatidylglycerol, by trypsin, releasing lysine and phosphatidylglycerol.

A number of very appealing reasons led us to undertake this study. The properties of trypsin are well known, it is easy to obtain in pure form, and has recently been used in model membrane systems ${ }^{1}$ and as a probe for exploring the structure

* Present address (address for reprint requests) : Department of Biochemistry, A.R.C. Institute of Animal Physiology, Babraham, Cambridge, CB2 4AT, Great Britain. 
of natural membranes ${ }^{2-4}$. In addition, because trypsin's more usual action is not lipolytic, it is interesting to compare its effect on lysylphosphatidylglycerol monolayers with the action of lipases and phospholipases on lipid monolayers as reported by other workers. Moreover, the substrate may be readily prepared with a radioactive label in the lysyl moiety. Kinetic studies by the measurement of surface radioactivity are made possible by the solubility of the radioactive product lysine upon enzymic hydrolysis.

\section{MATERIALS AND METHODS}

Trypsin, purchased from Boeringer Mannheim Co., had a specific activity supplied of $\mathrm{I}_{7} 8$ munits/mg. A second trypsin preparation (chymotrypsin-free, Serva Heidelberg, Germany), used in some experiments had a specific activity of I05 munits $/ \mathrm{mg}$. The activities of the two trypsin preparations on lysylphosphatidylglycerol were both proportional to their specific activities.

$\left[{ }^{14} \mathrm{C}\right]$ Lysine (3I2 mCi/mmole) was obtained from New England Nuclear. ${ }^{45} \mathrm{CaCl}_{2}$ (approx. $87 \mathrm{mCi} / \mathrm{mmole}$ ) was obtained from the Radiochemical Centre, Amersham, England, and was diluted to appropriate concentrations with unlabelled $\mathrm{CaCl}_{2}$.

\section{Preparation of $\left[{ }^{14} \mathrm{C}\right]$ lysylphosphatidylglycerol}

Radioactive lysylphosphatidylglycerol was prepared by a slight modification of the procedure of Gould and Lennarz ${ }^{5}$. Staphylococcus aureus 292, a penicillinresistant, lysine-auxotroph, was grown to mid logarithmic phase in Ioo $\mathrm{ml}$ of peptone media. The cells were washed twice with $0.05 \mathrm{M}$ Tris buffer ( $\mathrm{pH} \mathrm{7.2)} \mathrm{and}$ then resuspended in $25 \mathrm{ml}$ of this buffer. To the cell suspension was added $\left[{ }^{14} \mathrm{C}\right]$ lysine (50 $\mu \mathrm{Ci}$; o.I6 $\mu$ mole) and the cells were incubated for one hour at $37^{\circ} \mathrm{C}$. The suspension was acidified with $\mathrm{HCl}$ to $\mathrm{pH} 2.0$ and then extracted with chloroformmethanol $(\mathrm{x}: \mathrm{I}, \mathrm{v} / \mathrm{v})$ according to the procedure of Bligh and Dyer ${ }^{6}$. The lysylphosphatidylglycerol was isolated by silicic acid chromatography and DEAE-cellulose chromatography as previously described ${ }^{7}$. Purification on thin-layer chromatographic plates was not necessary when the silicic acid column was run before the DEAE column.

\section{Monolayer techniques}

The apparatus and techniques for determination of the surface pressure and surface radioactivity have already been described $^{8}$. In some experiments where changes in the surface pressure with time were followed, the stirring rate was reduced from 34 cycles/min to Io cycles/min. All experiments were run at room temperature. No detectable variability in hydrolysis was observed in day-to-day controls.

In some experiments EDTA $(0.05 \mathrm{mM})$ was used to remove any contaminating heavy metals. Force-area curves were determined on a Teflon trough $(25 \mathrm{~cm} \times 17 \cdot 3$ $\mathrm{cm}$ surface): the surface pressure being measured by a Wilhelmy plate method ${ }^{9}$ although in some experiments a Langmuir surface balance was used.

\section{RESULTS}

Surface properties of lysylphosphatidylglycerol, phosphatidylglycerol and a mixed film of the two phospholipids

The force-area curves of the substrate lysylphosphatidylglycerol and product 
phosphatidylglycerol were examined (Fig. I). As also found by Haest et $a .^{10}$, the lysylphosphatidylglycerol films have a more expanded nature, i.e. greater area per molecule, than the phosphatidylglycerol films. This difference is presumably due to the increased size or the differing net charge of the polar head group of lysylphosphatidylglycerol, since the fatty acid composition of these phospholipids is rather similar ${ }^{\mathbf{1 0}}$.

Since the reaction proceeds on a mixed film of lysylphosphatidylglycerol and phosphatidylglycerol, force-area curves of mixtures of the two lipids were examined by a Wilhelmy plate method (Fig. r). A mixed film containing $75 \%$ molar phosphatidylglycerol and $25 \%$ molar lysylphosphatidylglycerol gave identical force-area curves, either in the presence or absence of calcium in the subphase, which had a more expanded character than those calculated from their individual force-area curves. This result indicated that the positive groups of the lysyl moiety might be raised more into the surface than in pure lysylphosphatidylglycerol films, due to an electrostatic interaction with phosphate groups on adjacent phosphatidylglycerol molecules. Similar observations were made with a Langmuir surface balance.

As found by Rojas and Tobias ${ }^{11}$ for the acidic phosphatidylserine, $\mathrm{Ca}^{2+}$ (at the levels used in the enzyme reaction) caused a slight reduction in the area per molecule of the acidic phosphatidylglycerol film and had no effect on the lysylphosphatidylglycerol film. This decrease is presumably due to a reduction in the electrostatic repulsion between the negatively charged polar groups of phosphatidylglycerol brought about by the adsorbed divalent $\mathrm{Ca}^{2+}$.
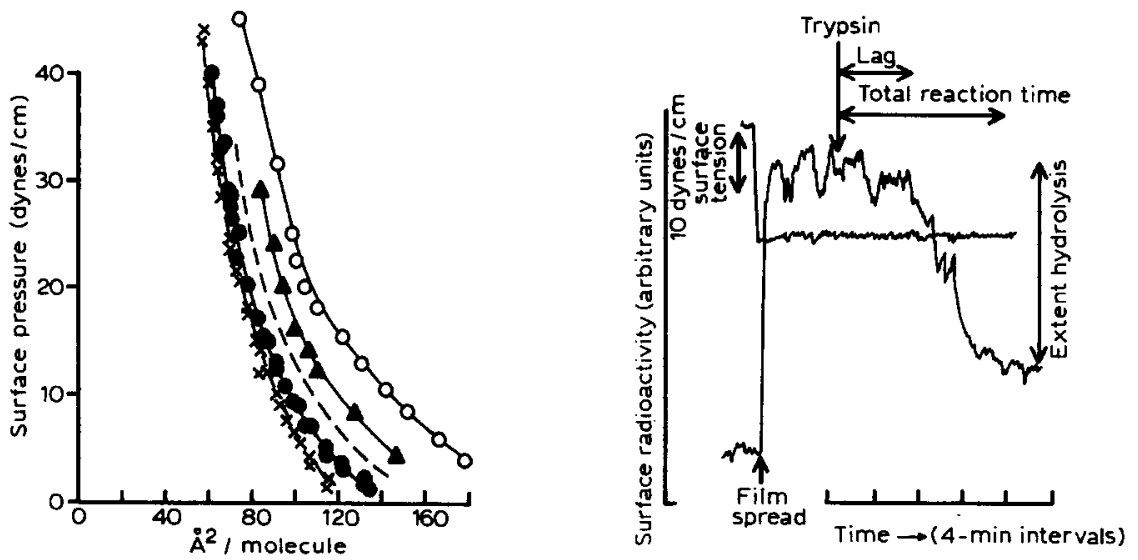

Fig. I. Surface pressure-area per molecule curves of monomolecular films of phosphatidylglycerol (O-O), phosphatidylglycerol $+\mathrm{Ca}^{2+}(x-\times)$, lysylphosphatidylglycerol $(0-0)$, and a mixture of phosphatidylglycerol $(75 \%$ molar $)+1$ ysylphosphatidylglycerol $(25 \%$ molar $)$ either with or without $\mathrm{Ca}^{2+}(\mathbf{A}-\mathbf{A})$. A theoretical curve of this mixed film is also shown $(---)$. The subphase was $3 \mathrm{mM}$ Tris- $\mathrm{HCl}$ buffer ( $\mathrm{pH} 7.8$ ) containing where indicated $200 \mu \mathrm{M}$ $\mathrm{CaCl}_{2}$.

Fig. 2. Recording of hydrolysis of $\left[{ }^{14} \mathrm{C}\right]$ lysylphosphatidylglycerol by to $\mu \mathrm{g}$ of trypsin (chymotrypsin-free, Serva). The surface pressure was recorded with a dipping needle, as the subphase was stirred at Io cycles/min. The subphase contained $3 \mathrm{mM}$ Tris- $\mathrm{HCl}$ (pH 7.6 ), I25 $\mu \mathrm{M} \mathrm{CaCl}_{2}$ and 5o $\mu \mathrm{M}$ EDTA. The Iysylphosphatidylglycerol $(35000 \mathrm{cpm}$, spec. act. 5.0 $\mu \mathrm{Ci} / \mu \mathrm{mole})$ was spread in $25 \mu \mathrm{l}$ of chloroform-methanol $(9: \mathrm{I}, \mathrm{v} / \mathrm{v})$ at an initial pressure of 20 dynes/cm. Surface radioactivity is recorded in arbitrary units. The enzyme activity is calculated as a percentage decrease per min based on the total lysylphosphatidylglycerol added. 
General properties of the enzymic reaction and enzyme concentration dependency

The hydrolysis of monomolecular films of lysylphosphatidylglycerol by trypsin was most easily followed by continuous surface radioactivity measurements of a

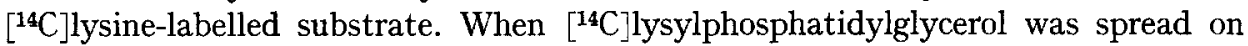
a buffered solution containing a divalent cation, the surface radioactivity increased and then stabilized at a constant level. At 20 dynes $/ \mathrm{cm}$ surface pressure this increase was approximately ten times the background value. The alkaline labile ester linkage of the lysine was not appreciably hydrolysed at $\mathrm{pH} 8.0$ in $2 \mathrm{~h}$ as measured by the stability of the surface radioactivity. However, as is shown in Fig. 2, when Io $\mu \mathrm{g}$ of trypsin was added to the subphase $(80 \mathrm{ml}$ ), after a few minutes lag (a slow hydrolysis reaction may occur during this period) a rapid hydrolysis of lysylphosphatidylglycerol ensued. The reaction proceeded at a constant rate until $50-85 \%$ of the lysylphosphatidylglycerol had been hydrolysed. This rapid change in surface radioactivity was accompanied by only a slight decrease in surface pressure. This decrease was always less than could be predicted from the force-area curves of lysylphosphatidylglycerol and phosphatidylglycerol and their mixture (Fig. I), a result which might be explained by the penetration of protein into the film. The subphase was stirred during the hydrolysis of lysylphosphatidylglycerol. Without stirring the rate of hydrolysis was somewhat lower.

Various parameters of the reaction such as maximal reaction rate, the reaction time, the lag or slow hydrolysis time and the extent of hydrolysis can be obtained from the radioactive tracing (Fig. 2). Table $I$ includes the measurements of these various parameters as a function of enzyme concentration. As expected, the rate of the hydrolysis is increased with enzyme concentration, whereas the lag or slow hydrolysis time and the total reaction time are shortened. The extent of the reaction seems to be independent of the enzyme concentration. When the reaction rate is plotted as a function of enzyme concentration (Fig. 3), a linear relationship is obtained over the range from o to $0.125 \mu \mathrm{g} / \mathrm{ml}$ : above this enzyme level the increase in reaction rate per increment of protein tends to fall.

\section{TABLE I}

VARIATION OF REACTION PARAMETERS WITH ENZYME CONCENTRATION

The subphase $(80 \mathrm{ml})$ contained $6 \mathrm{mM}$ Tris-acetate, $\mathrm{pH} 7.6$ and $0.3 \mathrm{mM} \mathrm{CaCl}$. The substrate [ $\left.{ }^{14} \mathrm{C}\right]$ lysylphosphatidylglycerol $(35000 \mathrm{cpm}$, spec. act. $7.5 \mathrm{mCi} / \mathrm{mmole})$ was spread from $25 \mu \mathrm{l}$ of chloroform-methanol $(9: \mathrm{r}, \mathrm{v} / \mathrm{v})$, with a micrometer syringe (Agla, Burroughs Welcome). The pressure was adjusted to 20 dynes $/ \mathrm{cm}$ with a movable barrier. The reaction was initiated by adding trypsin $(0.5 \mathrm{mg} / \mathrm{ml}$ ) (Boeringer-Mannheim, spec. act. 178 munits $/ \mathrm{mg}$ ) with a micropipette, directly under the barrier.

\begin{tabular}{llllll}
\hline $\begin{array}{l}\text { Trypsin } \\
\text { added } \\
(\mu g)\end{array}$ & $\begin{array}{l}\text { Enzyme } \\
\text { concn } \\
(\mu g / m l)\end{array}$ & $\begin{array}{l}\text { Maximum } \\
\text { reaction rate } \\
(\% \text { hydrolysis/min })\end{array}$ & $\begin{array}{l}\text { Total } \\
\text { reaction time } \\
(\text { min })\end{array}$ & $\begin{array}{l}\text { Lag or slow } \\
\text { hydrolysis } \\
\text { period }(\text { min })\end{array}$ & $\begin{array}{l}\text { Extent of } \\
\text { hydrolysis } \\
(\%)\end{array}$ \\
\hline & & & & & 76 \\
1.0 & 0.0125 & 2.8 & 38 & 17 & 84 \\
2.5 & 0.0312 & 6.3 & 29 & 5 & 84 \\
5.0 & 0.0625 & 12.5 & 11 & 2.5 & 84 \\
10.0 & 0.125 & 20.5 & 7 & 2 & 86 \\
20 & 0.25 & 31.5 & 5 & 1 & \\
40 & 0.50 & 60 & 4 & &
\end{tabular}




\section{$p H$ and ionic requirements}

The $\mathrm{pH}$-activity profile of the reaction (Fig. 4) shows that the rate is maximal between $\mathrm{pH} 7.5$ and 8.5 , whereas no reaction occurs below $\mathrm{pH}$ 5.5. Measurements above $\mathrm{pH} 8.5$ were not made because of alkaline lability of the substrate. The $\mathrm{pH}$ curve is quite similar to that of the reaction of trypsin on $\alpha-N$-benzyl-L-argininamide ${ }^{12}$.

The dependence of the hydrolysis on $\mathrm{Ca}^{2+}$ is shown in Fig. 5. A maximal reaction rate is obtained at $\mathrm{ro}^{-5}-5 \cdot \mathrm{IO}^{-4} \mathrm{M} \mathrm{CaCl}_{2}$. In the absence of $\mathrm{Ca}^{2+}$, a very slow reaction was observed which produced never more than $50 \%$ hydrolysis of the lysylphosphatidylglycerol substrate. This slow hydrolysis was not due to traces of calcium in the solutions as it persisted even in the presence of $\mathrm{Io}^{-3} \mathrm{M}$ EDTA. Above $5 \cdot \mathrm{IO}^{-4}$ $\mathrm{M} \mathrm{CaCl}_{2}$ the reaction was greatly inhibited and a rate of less than ro $\%$ of the optimal was found at $3 \cdot \mathrm{IO}^{-3} \mathrm{M} \mathrm{Ca}^{2+}$. The stimulatory effect of $\mathrm{Ca}^{2+}$ cannot be simply
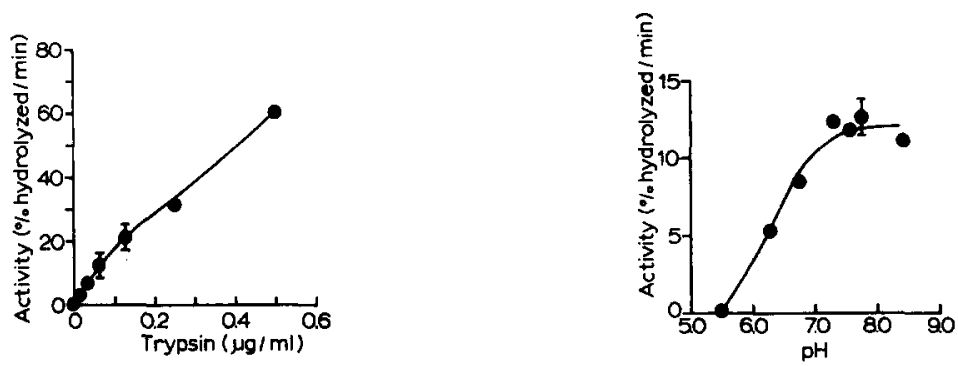

Fig. 3. Variation of the reaction velocity with enzyme concentration. Conditions for the reaction are described in Table I.

Fig. 4. Variation of the reaction velocity with $\mathrm{pH}$. Tris-acetate buffers were used at $6 \mathrm{mM}$ Tris. The acetate concentration was adjusted to give the appropriate $\mathrm{pH}$. The reaction conditions are as in Table I. Reactions were initiated with $5 \mu \mathrm{g}$ trypsin.
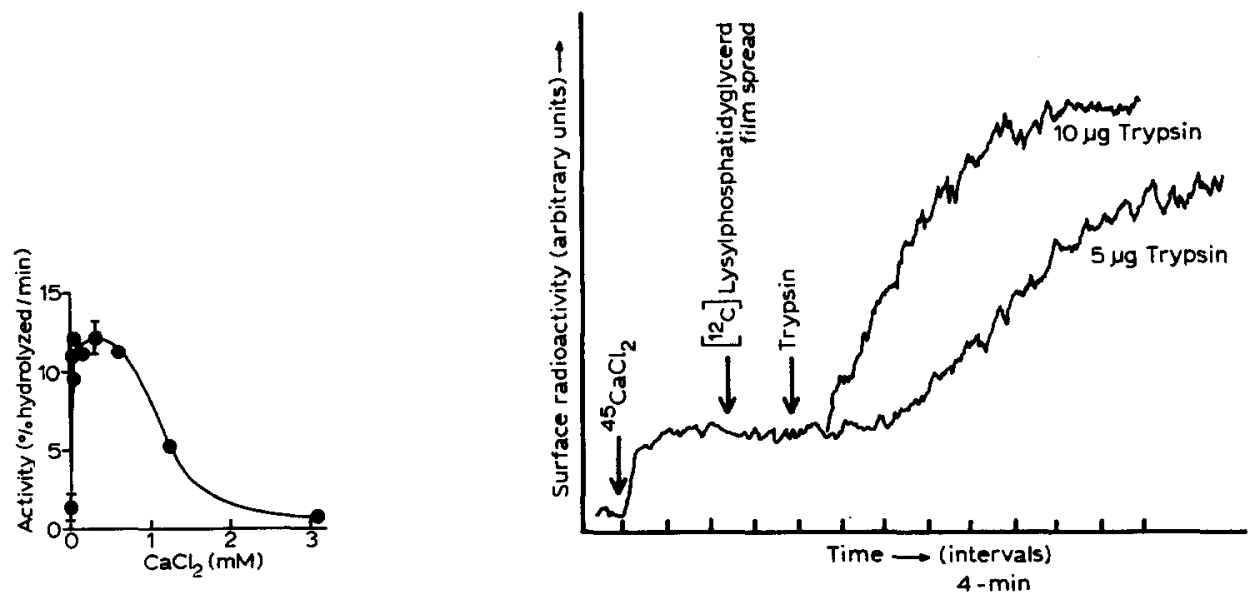

Fig. 5. Variation of the reaction velocity with $\mathrm{Ca}^{2+}$ concentration. The reaction was carried out as in Table I except that the $\mathrm{Ca}^{2+}$ concentration was varied. Reactions were initiated with $5 \mu \mathrm{g}$ trypsin.

Fig. 6. Measurements of the binding of ${ }^{45} \mathrm{Ca}^{2+}$ to the monolayer. Unlabelled lysylphosphatidylglycerol was spread (20 dynes/cm) on a subphase of $6 \mathrm{mM}$ Tris acetate $(\mathrm{pH} 7.6)$ containing $3 \mu \mathrm{M}{ }^{45} \mathrm{Ca}^{2+}$ (spec. act. $0.35 \mu \mathrm{Ci} / \mu$ mole). The reactions were initiated by the addition of trypsin ( 178 munits $/ \mathrm{ml}$ ) as indicated. Radioactivity measurements are in arbitrary units. 
explained by the ionic strength increase because added $\mathrm{NaCl}$ at all concentrations did not stimulate.

As $\mathrm{Ca}^{2+}$ is known both to activate and to stabilize trypsin ${ }^{13}$ as well as to interact with negatively charged phospholipids ${ }^{11,14}$ such as phosphatidylglycerol, the stimulating effect of calcium on the reaction was further examined with radioactive $\mathrm{Ca}^{2+}$. In Fig. 6 tracings of the time course of adsorption of ${ }^{45} \mathrm{Ca}^{2+}$ onto the monolayer surface are followed at two separate enzyme concentrations. Before the addition of enzyme no binding of $\mathrm{Ca}^{2+}$ onto the positively charged lysylphosphatidylglycerol surface was observed.

Once trypsin is added, after the characteristic lag, $\mathrm{Ca}^{2+}$ rapidly binds to the monolayer reflecting its interaction with the negatively charged product, phosphatidylglycerol. The rate of binding is roughly proportional to the amount of enzyme added (4.I \% of total adsorption per min for $5 \mu \mathrm{g}$ trypsin and $7.3-9.2 \%$ of total adsorption per min for Io $\mu$ g trypsin). The rate of ${ }^{45} \mathrm{Ca}^{2+}$-binding in these experiments is considerably lower than the rate of hydrolysis previously measured by solubilization of radioactive lysine (I2.5\% per min for $5 \mu \mathrm{g}$ trypsin and $20.5 \%$ per min for Io $\mu \mathrm{g}$ trypsin, Table I, Fig. 3) possibly because in the former experiment the concentration of $\mathrm{Ca}^{2+}$ was insufficient to produce maximum hydrolysis. The importance of $\mathrm{Ca}^{2+}$ in the hydrolysis was further emphasized by the ability of EDTA to inhibit the reaction, even after it had already begun. In control experiments it was found that EDTA rapidly removes ${ }^{45} \mathrm{Ca}^{2+}$ from phosphatidylglycerol monolayers. A

TABLE II

EFFECT OF CATIONIC SPECIES ON REACTION

The subphase $(80 \mathrm{ml})$ contained $3 \mathrm{mM}$ Tris- $\mathrm{HCl}, \mathrm{pH} 7.6 . \mid\left[{ }^{14} \mathrm{C}\right] \mathrm{Lysylphosphatidylglycerol} \mathrm{was}$ added to give a surface pressure of 20 dynes $/ \mathrm{cm}$. The salts were added as indicated prior to the spreading of the film. Where indicated $5^{\circ} \mu \mathrm{M} \mathrm{EDTA}\left({ }^{*}\right)$ or Io $\mu \mathrm{M}$ of $\mathrm{CaCl}_{2}\left({ }^{*}\right)$ were also added. Reaction was initiated with ro $\mu \mathrm{g}$ of trypsin (Serva).

\begin{tabular}{|c|c|c|c|}
\hline Salt & $\begin{array}{l}\text { Concn of salt added } \\
(\mu M)\end{array}$ & $\begin{array}{l}\text { Rate hydrolysis } \\
(\% \text { hydrolysis/min })\end{array}$ & $\begin{array}{l}\text { Extent hydrolysis } \\
(\%)\end{array}$ \\
\hline $\mathrm{CaCl}_{2}$ & $\begin{array}{c}30 \\
125 \\
125\end{array}$ & $\begin{array}{l}\text { I I } \\
\text { I2 } \\
\text { I } 2.5\end{array}$ & $\begin{array}{l}72 \\
66 \\
63\end{array}$ \\
\hline $\mathrm{SrCl}_{2}$ & $\begin{array}{r}25 \\
\mathrm{I} 25 \\
375^{*}\end{array}$ & $\begin{array}{l}9.2 \\
5.2 \\
7.7\end{array}$ & $\begin{array}{l}71 \\
66 \\
7 x\end{array}$ \\
\hline $\mathrm{MgCl}_{2}$ & $\begin{array}{r}30 \\
125 \\
375^{*}\end{array}$ & $\begin{array}{l}7.5 \\
6.0 \\
6.5\end{array}$ & $\begin{array}{l}82 \\
62 \\
72\end{array}$ \\
\hline $\mathrm{NaCl}$ & 600 & 2.0 & 47 \\
\hline $\mathrm{UO}_{2}\left(\mathrm{NO}_{3}\right)_{2}$ & $\begin{array}{r}12.5 \\
3.0^{* *}\end{array}$ & $\begin{array}{l}0.0 \\
0.0\end{array}$ & - \\
\hline $\operatorname{Th}\left(\mathrm{NO}_{3}\right)_{4}$ & $\begin{array}{r}12.5 \\
3.0 * *\end{array}$ & $\begin{array}{l}0.0 \\
0.0\end{array}$ & - \\
\hline No salt & 二。 & $\begin{array}{l}2.7 \\
2.4\end{array}$ & $\begin{array}{l}50 \\
44\end{array}$ \\
\hline
\end{tabular}


number of other cations were tested to see if they could stimulate the hydrolysis of lysylphosphatidylglycerol by trypsin (Table II). Both $\mathrm{Mg}^{2+}$ and $\mathrm{Sr}^{2+}$ were found to be stimulatory. In the presence of $0.05 \mathrm{mM}$ EDTA (see Table II) which was added to reduce stimulation by contaminating $\mathrm{Ca}^{2+}$, these ions gave a somewhat lower stimulation than that of $\mathrm{Ca}^{2+}$ at concentrations where $\mathrm{Ca}^{2+}$ stimulation was maximal.

To see if cations of a different valency could effectively stimulate the reaction, $\mathrm{Na}^{+}$, uranyl and thorium ions were tested. $\mathrm{Na}^{+}$alone had no significant stimulatory effect on the hydrolytic reaction. However, as will be indicated later, $\mathrm{NaCl}$ can either slightly stimulate the calcium-catalyzed reaction or totally inhibit it. Uranyl and thorium ions completely inhibited any hydrolysis of the phospholipid, even when $\mathrm{Ca}^{2+}$ were subsequently added to the subphase (see ${ }^{\star}$ Table II). Both uranyl and thorium ions effectively interact with monomolecular layers of negatively charged lipids ${ }^{15,16 .}$

\section{Inhibition of the reaction}

Although $\mathrm{Ca}^{2+}$ stimulates the reaction, at higher concentrations it becomes strongly inhibitory (Fig. 5). Not only $\mathrm{Ca}^{2+}$, but also the Tris buffer concentration was crucial for optimal hydrolysis (Fig. 7A). In the presence of $125 \mu \mathrm{M} \mathrm{Ca}^{2+}$, only a limited hydrolysis was observed with a Tris concentration below $0.5 \mathrm{mM}$. With an optimal reaction at Tris concentrations ranging from 2.5 to $30 \mathrm{mM}$, the rate was reduced to the non- $\mathrm{Ca}^{2+}$ requiring level at $47 \mathrm{mM}$ Tris. If the sole effect of Tris was to compete with $\mathrm{Ca}^{2+}$ at the monolayer, higher concentrations of $\mathrm{Ca}^{2+}$ should stimulate the reaction to its optimal level. When the $\mathrm{Ca}^{2+}$ concentration was doubled (Fig. $7 \mathrm{~A}^{*}$ ), the reaction rate was increased, but not to the level obtained with optimal Tris concentrations.

Apart from Tris, a salt such as $\mathrm{NaCl}$ strongly affected the $\mathrm{Ca}^{2+}$-catalysed reaction rate (Fig. $7 \mathrm{~A}$ ). At I25 $\mu \mathrm{M} \mathrm{Ca}^{2+}$, low levels of $\mathrm{NaCl}$ stimulated slightly the reaction rate. In addition, a complete inhibition of the $\mathrm{Ca}^{2+}$-stimulated reaction was observed at roughly one-half the concentration at which maximal inhibition by Tris occurred.

Many basic drugs such as procaine and chlorpromazine can, at very low concentrations, displace $\mathrm{Ca}^{2+}$ adsorbed on to monomolecular layers of acidic phos-
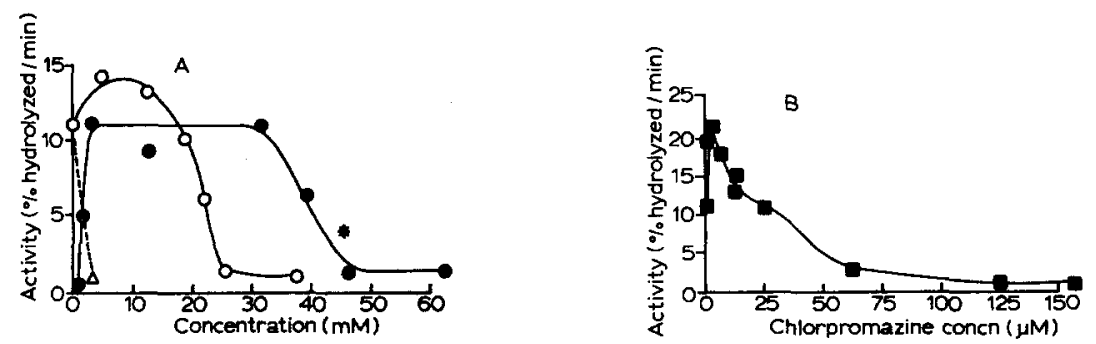

Fig. 7. Effect of $\mathrm{CaCl}_{2}, \mathrm{Tris}-\mathrm{HCl}, \mathrm{NaCl}$ and chlorpromazine on the reaction velocity. The lysylphosphatidylglycerol and trypsin were added and other conditions are as described in Fig. 2. The basic subphase contained $3 \mathrm{mM}$ Tris- $\mathrm{HCl}(\mathrm{pH} 7.6), 125 \mu \mathrm{M} \mathrm{CaCl}_{2}$ and $50 \mu \mathrm{M}$ EDTA. (A) In the curve - the Tris- $\mathrm{HCl}$ concentration was varied while in the curve $\mathrm{O}-\mathrm{O} \mathrm{NaClwas}$ added. At point $\Delta$ the $\mathrm{Ca}^{2+}$ concentration was increased to $3 \mathrm{mM}$ while at $* \mathrm{Ca}^{2+}$ had been increased to $25^{\circ} \mu \mathrm{M}$ and Tris- $\mathrm{HCl}$ to $47 \mathrm{mM}$. (B) Chlorpromazine added. 
pholipids ${ }^{17}$. Since $\mathrm{Ca}^{2+}$ seem to play a very significant part in the trypsin-catalyzed hydrolysis, the effect of chlorpromazine was examined (Fig. $7 \mathrm{~B}$ ). At I25 $\mu \mathrm{M} \mathrm{CaCl}_{2}$, chlorpromazine had a striking effect on the hydrolysis rate. As might be predicted from its ability to compete with $\mathrm{Ca}^{2+}$ at a lipid-water interface, chlorpromazine inhibited, the hydrolysis at levels comparable to that of the free $\mathrm{Ca}^{2+}$. At these concentrations of chlorpromazine, $25-\mathrm{I} 25 \mu \mathrm{M}$, the addition of the drug was accompanied by a 3-5 dyne/cm increase in the surface pressure. At lower chlorpromazine concentrations, $2.5-6 \mu \mathrm{M}$, there was a dramatic increase of the reaction rate. Such a rapid reaction could not be obtained with $\mathrm{Ca}^{2+}$. In the absence of $\mathrm{Ca}^{2+}$, chlorpromazine was not able to stimulate the reaction.

\section{Substrate concentration varied by changes in the surface pressure}

The effect of the initial surface pressure on the rate of hydrolysis was examined (Fig. 8). Maximum hydrolysis occurred at pressures from to to $35 \mathrm{dynes} / \mathrm{cm}$. Above and below these values the reaction rate was significantly reduced.

The lag or slow hydrolysis period increased significantly at high pressures. One possible explanation for this increase is that during the lag or slow hydrolysis period, some cleavage of the lysylphosphatidylglycerol takes place. The slow hydrolysis may allow more enzyme to penetrate the monolayer and result in an accelerated reaction. To test this possibility the reaction of trypsin on pure lysylphosphatidylglycerol and a substrate containing ro $\%$ phosphatidylglycerol were compared. The experiments were run just below the collapse pressures of the lipids, 46 and 43 dynes $/ \mathrm{cm}$, respectively. The results of this experiment are presented in Fig. 9. When phosphatidylglycerol was added to the lysylphosphatidylglycerol, the lag time was greatly reduced ( $17 \mathrm{~min}$ for pure lysylphosphatidylglycerol to $4 \mathrm{~min}$ for
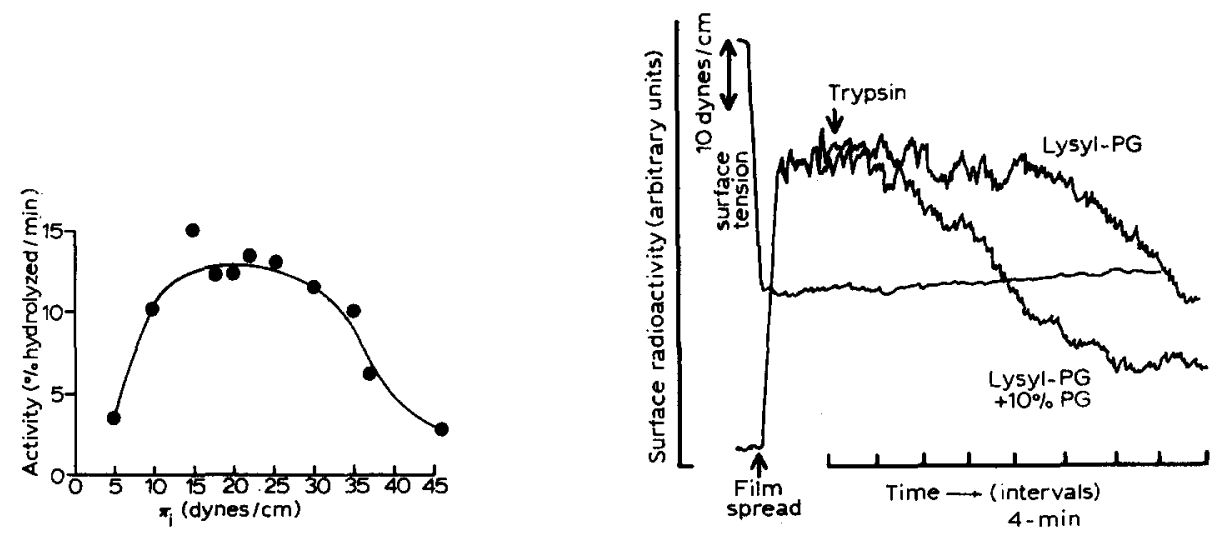

Fig. 8. Variation of the reaction velocity with initial surface pressure $\left(\pi_{1}\right)$. Lysylphosphatidylglycerol was added to the surface and the pressure was adjusted with a movable barrier. The subphase conditions were as described in Table I. The reaction was initiated with $5 \mu \mathrm{g}$ of trypsin.

Fig. 9. Effect of phosphatidylglycerol (PG) on the slow hydrolysis reaction at high pressures. $\left[{ }^{14} \mathrm{C}\right]$ Lysylphosphatidylglycerol was added to produce a film of 46 dynes $/ \mathrm{cm}$. In a second

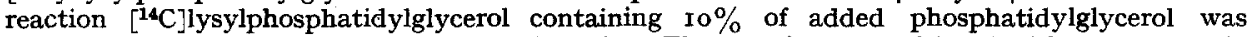
spread to produce a film pressure of $43 \mathrm{dynes} / \mathrm{cm}$. The reaction was initiated with Io $\mu \mathrm{g}$ trypsin (spec. act. 105 munits/mg). Bulk conditions are as described in Fig. 2. 
the mixed film), whereas the reaction rates were very similar $(2.9 \%$ per min for pure lysylphosphatidylglycerol to $3.5 \%$ per min for the mixed film).

\section{DISCUSSION}

Surface radioactivity measurements of monolayers containing $\left[{ }^{\mathbf{1 4}} \mathrm{C}\right]$ lysylphosphatidylglycerol or of the unlabelled substrate on subphases containing ${ }^{45} \mathrm{Ca}^{2+}$ have both been used to study the hydrolysis of lysylphosphatidylglycerol by the protease, trypsin. The findings that the rates of the enzymic reaction as measured by percent hydrolysis per min of the labelled substrate, or the percent binding of radioactive $\mathrm{Ca}^{2+}$ per min are proportional to the bulk enzyme concentration, signify that quantitative experimentation is plausible. In addition, the linear rate of hydrolysis indicates that the substrate (approx. Io nmoles per experiment) is in excess during much of the reaction. This observation is consistent with investigations of enzymic attack of lipid monolayers by lipases ${ }^{18-20}$ and phospholipases ${ }^{9,21-24}$. The difficulties in determining the surface enzyme concentration ${ }^{9,23}$ make precise quantitative evaluation of the kinetic parameters $V$ and $K_{m}$ unfeasible.

The trypsin-catalyzed breakdown of lysylphosphatidylglycerol is limited to a very narrow range of subphase conditions. Very low concentrations of $\mathrm{CaCl}_{2}$ (o.or $\mathrm{mM}$ ) together with $\mathrm{NaCl}(5 \mathrm{mM})$ and Tris buffer $(2 \mathrm{mM})$ greatly accelerate the hydrolysis, whereas at higher concentrations of $\mathrm{NaCl}(25 \mathrm{mM})$, Tris buffer $(50 \mathrm{mM})$ and $\mathrm{CaCl}_{2}(3 \mathrm{mM})$ a pronounced inhibition of hydrolysis was observed.

One explanation for these stimulatory effects could be that salt is required to reduce the electrostatic repulsion of trypsin (positively charged below $\mathrm{pH} 9.3$ ) as a whole molecule or its active center by the positively charged interface. Once the reaction has begun, these ions might additionally decrease an inhibitory binding of enzyme to the acidic phosphatidylglycerol. A similar action of ionic strength has been proposed for reducing the inhibition of trypsin by anionic copolymers ${ }^{25}$. The stimulation is not simply an artifact due to an ionic requirement for the liberation of the positively charged lysine from the negatively charged lipoidal product in the surface. Thus when a reaction limited by a low Tris concentration $(0.5 \mathrm{mM})$ is stimulated by addition of Tris $(2 \mathrm{mM}),\left[{ }^{14} \mathrm{C}\right]$ lysine is not immediately liberated from the interface, but the hydrolysis commences only after a characteristic lag and to a rate dependent on the trypsin concentration.

The ability of all these solutes, including the activating $\mathrm{Ca}^{2+}$, to inhibit the reaction may imply that at high concentrations these ions compete with the basic protein trypsin ( $\mathrm{pH}$ 9.3) for sites in the monolayer film. All of these findings point to the importance of electrostatic interactions in the reaction. Such strong sensitivities to ionic components have not been found in the lipolytic attack of lipases ${ }^{18,19}$ and phospholipases ${ }^{\mathbf{9}, 21-24,26}$ on monomolecular films of substrate.

The above discussion does not elucidate the specific requirement for $\mathrm{Ca}^{2+}$ in the reaction. A specific $\mathrm{Ca}^{2+}$ requirement has also been found for the hydrolysis of lecithin by phospholipase $D^{22}$, but not by phospholipase $C^{27}$. Since in the phospholipase $\mathrm{D}$ and trypsin hydrolyses a negatively charged interface is formed and also because $\mathrm{Ca}^{2+}$ shows high affinity for acidic phospholipids ${ }^{11,14}$, the stimulation of $\mathrm{Ca}^{2+}$ may be a result of its interaction with phosphatidic acid and phosphatidyl glycerol, respectively. Further evidence for the interaction of $\mathrm{Ca}^{2+}$ with the phos- 
phatidylglycerol formed comes from the finding that the reaction can be followed by adsorption of radioactive $\mathrm{Ca}^{2+}$ onto the interface. Additional support for the lipid/water interfacial role of $\mathrm{Ca}^{2+}$ comes from the inhibition by EDTA which rapidly removes radioactive $\mathrm{Ca}^{2+}$ from phosphatidylglycerol monolayers, and by chlorpromazine which has a similar ability to remove $\mathrm{Ca}^{2+}$ from interfaces of acidic phospholipids ${ }^{17}$.

The other possible role of $\mathrm{Ca}^{2+}$ in stabilizing trypsin or increasing its penetration into the monolayer as an enzyme-ion complex cannot be ruled out. The stabilizing and activating effects of $\mathrm{Ca}^{2+}$ on trypsin in bulk are found with similar $\mathrm{Ca}^{2+}$ concentrations ${ }^{13}$. However, the $\mathrm{Ca}^{2+}$-requiring activation of trypsinogen by trypsin is believed to be a result of interaction of $\mathrm{Ca}^{2+}$ with negatively charged aspartyl residues of the substrate trypsinogen and not with the enzyme ${ }^{28}$.

Trypsin is able to cleave lysylphosphatidylglycerol over a wide range or surface pressures. As has been observed with lipases and phospholipases, its action is decreased at both very high and very low initial pressures. The reduction of trypsin hydrolysis of lysylphosphatidylglycerol at pressures approaching collapse ( 45 dynes $/ \mathrm{cm}$ ) is in agreement with the idea that the reaction can be limited by tight packing of the substrate molecules and the consequent high charge density of the interface. This packing may prevent the ready penetration of the active centre of the enzyme between the polar head groups of the substrate. One explanation for the lag period, which increases at high initial surface pressures, could be that a slow hydrolysis of the lipid produces negative sites on the film which attract enzyme molecules so that the reaction becomes autocatalytic. Thus addition of phosphatidylglycerol to the film at high pressure reduces the observed lag phase. This explanation is consistent with the enhancement of lecithin hydrolysis at high surface pressures by phospholipase D resulting from the addition of phosphatidic acid to the film ${ }^{22}$.

\section{ACKNOWLEDGEMENTS}

R. M. G. was supported by grant PF 575 from The American Cancer Society. The authors would like to express their appreciation to Dr Cliff Woodward, III and Dr Karel Wirtz for critical reading of the manuscript.

\section{REFERENCES}

I E. Katchalski, in P. Desnuelle, H. Neurath and M. Ottesen, Structure-Function Relationships of Proteolytic Enzymes, Munksgaard, Copenhagen, 1970, pp. 198-22I.

2 T. L. Steck, G. Fairbanks and D. F. H. Wallach, Biochemistry, Io (1971) 26r7.

3 G. Wintzer and G. Uhlenbruck, Z. Klin. Chem. Klin. Biochem., 9 (1971) 266.

4 I. Tasaki and T. Takenake, Proc. Natl. Acad. Sci., U.S., 52 (I964) 804.

5 R. M. Gould and W. J. Lennarz, J. Bacteriol., I04 (1970) II 35.

6 E. G. Bligh and W. J. Dyer, Can. J. Biochem. Physiol., 37 (I959) 9 I I.

7 U. Hopfer, A. L. Lehninger and W. J. Lennarz, J. Membrane Biol., 2 (1970) 4I.

8 R. M. C. Dawson, in J. M. Lowenstein and R. B. Clayton, Methods in Enzymology, Vol. I4, New York, Academic Press, 1969, pp. 633-648.

9 G. Zografi, R. Verger and G. H. de Haas, Chem. Phys, Lipids, 7 (I97I) I 85.

Io C. W. M. Haest, J. de Gier, J. A. F. Op den Kamp, P. Bartels and L. L. M. van Deenen, Biochim. Biophys. Acta, 255 (1972) 720.

II E. Rojas and J. M. Tobias, Biochim. Biophys. Acta, 94 (1965) 394.

I2 W. E. Spomer and J. F. Wootton, Biochim. Biophys. Acta, 235 (x97 I) 164. 
I3 T. Sipos and J. R. Merkel, Biochemistry, 9 (1970) 2766.

I 4 H. Hauser and R. M. C. Dawson, Eur. J. Biochem., I (1967) 6I.

I5 A. D. Bangham and R. M. C. Dawson, Biochem. J., 72 (I959) 486.

I6 A. D. Bangham, J. de Gier and G. D. Greville, Chem. Phys. Lipids, I (I967) 225.

I7 H. Hauser and R. M. C. Dawson, Biochem. J., Iog (I968) 909.

I8 J. W. Lagocki, N. D. Boyd, J. H. Law and F. J. Kezdy, J. Am. Chem. Soc., 92 (1970) 2923.

r9 C. W. Garner and L. C. Smith, Biochem. Biophys. Res. Commun., 39 (I970) $67^{2}$.

20 J. Olive and D. D. Dervichian, Biochimie, 53 (197I) 207.

2 I R. M. C. Dawson, Biochem. $J$, 98 (I966) 35 C.

22 R. H. Quarles and R. M. C. Dawson, Biochem. J. II3 (I969) 697.

23 I. R. Miller and J. M. Ruysschaert, J. Colloid Interface Sci., 35 (I97 I) $34^{\circ}$.

24 G. Colacicco and M. M. Rapport, J. Lipid Res., 7 (1966) $25^{8}$.

25 M. Rigbi and M. Sela, Biochemistry, 3 (1964) 629.

26 D. O. Shah and J. H. Schulman, J. Colloid Interface Sci., 25 (1967) Io7.

27 A. D. Bangham and R. M. C. Dawson, Biochim. Biophys. Acta, 59 (1962) 103.

${ }_{28}$ M. Lazdunski, M. Delaage, J. P. Abita and J. P. Vincent, in P. Desnuelle, H. Neurath and M. Ottesen, Structure-Function Relationships of Proteolytic Enzymes, Munksgaard, Copenhagen, I970, pp. $4^{2-55}$.

Biochim. Biophys. Acta, 288 (1972) I $\rightarrow \mathrm{II}$ 